\title{
The Decreasing of Pancasila Values Implementation and Actualization on the Character of Indonesian Youth in the Digital Era
}

\author{
Silvia Devi, Lady Khairunnisa Adiyani, Ohara Cristhoper Panggabean, Linda Wulanika \\ silvia.devi-2020@fib.unair.ac.id; lady.khairunnisa.adiyani-2020@ fib.unair.ac.id; \\ ohara.cristhoper.panggabean-2020@ fib.unair.ac.id; linda.wulanika-2020@fib.unair.ac.id
}

Corresponding Author: Silvia Devi/silvia.devi-2020@fib.unair.ac.id

Faculty of Humanities Campus B Universitas Airlangga, Jalan Dharmawangsa Dalam

Surabaya, Indonesia. 60286. Phone: 031-5035807 Fax: 031-5035807

\begin{abstract}
:
Today, globalization and digitalization play a critical role in advancing science and technology in developing nations such as Indonesia. The change from a traditional to a digital environment has numerous positive and negative consequences. Globalization and digitalization have also successfully affected many elements of human life. In addition to delivering numerous valuable features and services for humans, the enormity of globalization and digitalization has a detrimental influence, particularly on young Indonesians. The crisis of character and morality among Indonesian young is significant, as seen by their current behavior, which is inconsistent with the character of the Indonesian country and the principles enshrined in Pancasila. Pancasila, which incorporates a variety of instruments, praxis, and axiological ideals, should serve as a guide for young people's behavior. This study investigates the influence of the deteriorating application of Pancasila's practical ideals in the daily lives of young people in the modern, digital era and how globalization impacts the moral degeneration of today's Indonesian youth. The researcher employs the process of Literature Review. The primary sources are literature studies in research papers, journals, and books. The absence of Pancasila ideals application and the expansion of globalization and digitalization among young people are diminishing and impacting the character of Indonesian youth. The application and execution of Pancasila's practical ideals among young Indonesians must be enhanced to prevent the nation's moral integrity from being undermined by the expanding currents of globalization and digitalization.
\end{abstract}

Keywords: Practical value, Pancasila, globalization, digitalization

\section{INTRODUCTION}

Pancasila is the foundation and ideology of the Indonesian people. Pancasila provides instrumental and practical ideals that guide all Indonesians to follow in their daily lives. Pancasila is also the nation's perspective on life, which prevents the Indonesian nation from being tossed and swayed when confronted with obstacles in the modern digital era. Every 
Indonesian citizen's life must be based on Pancasila ideals, and all Indonesian citizens' actions must implement Pancasila values. Not understanding and embodying Pancasila's ideals is the same as not displaying one's character as a member of the Indonesian nation. The Indonesian people's character and behavior must reflect the principles enshrined in Pancasila's five precepts. However, the nature of society, particularly of the Indonesian young, has recently deteriorated.

This is reflected in their everyday behavior and actions, making them seem no longer concerned with the moral values and praxis in Pancasila. They left their character following the values of the Pancasila points. Indonesian youths are gems and symbols of this country's great hope. Indonesian youth have a lot of potential and opportunities to make the Indonesian nation proud and lead the Indonesian nation towards a bright future. To achieve all the goals of the Indonesian nation contained in Pancasila and the Preamble to the 1945 Indonesian Constitution, young Indonesians must, of course, be able to maintain their national identity and character, which is by the values of Pancasila. Pancasila comes from the values and character of the Indonesian people themselves; therefore, young people must implement and embody the values of Pancasila in every behavior they do.

Great dreams and aspirations to realize the dream of the Indonesian state cannot be separated from the fact that they must have good moral character as the next generation of the Indonesian nation. The prosperity and peace of the country that we dream of will be better achieved if Indonesian citizens can practice Pancasila's values fully. On the other hand, if Indonesian youth's moral and moral behavior is terrible and even deviates from the principles of Pancasila, then the ideals of the country that are dreamed of will not be possible to achieve effectively. The presence of a fighting spirit and the unity of the strength of the younger generation in guarding the future of the Indonesian nation so that the welfare and ideals of the Indonesian nation can be achieved are the most important things for the progress of the Indonesian nation. There is nothing more potent than the dedication of the youth to the progress of their nation. The young generation holds the key to the future growth of our country.

The digital era and the globalization movement have had a detrimental influence on Indonesian youth and have a good one. The deterioration of moral values and character among the Indonesian young is the outcome of natural growth and change in the times, and it needs attention from various parties. This global and digital era appears to provide the younger generation the freedom to behave as they choose, both in the real world and on social media, with little concern for whether what they are doing is good or bad and following Pancasila's ideals or not. This may be seen in improper activities undertaken by young Indonesians, such as drug usage, free sex, propagating hoaxes, and other undesirable acts or behaviors. Currently, very few young people understand and behave according to the values of Pancasila.

Most of them only recognize and accept Pancasila as the basis and philosophy of the state without fully understanding its meaning and applying its practical values in everyday life. Pancasila is no longer entirely a guideline and way of life for Indonesian youth, and the values of Pancasila are now allowed to fade without any rescue efforts or comprehensive implementation. Pancasila, which should be a way of life, a national concept, and a state guideline, is now just a slogan. Young people who should be the hope and fighters for the ideals of the Indonesian nation have turned out to be desperate and have allowed the character of the Pancasila identity to fade. 


\section{METHOD}

The library study is a systematic scientific literature research endeavor that involves acquiring library resources relevant to article authoring, collecting procedures employing library methods, and structuring and presenting previously collected data. The approach employed is the Literature Review method, often known as the literature/library study method. The literature sources for this study were acquired from journals and scientific publications published on Google Scholar and preprints between 2019 and 2021. "Pancasila and Indonesian youth," "Pancasila practical values," and "Pancasila in the digital era." The inclusion criteria for the articles utilized are scholarly publications or journals on young people adopting Pancasila's practical ideals in the digital world. The scientific publication or journal must be published between 2019 and 2021, written in Indonesian or English, and have full-text access. This investigation has progressed through numerous levels. The first stage is gathering library materials in journals based on the subject. According to the essential criteria for picking a journal, as many articles as feasible can be collected. All sources of journals and scientific articles that have been collected are then read and understood by researchers. The researcher then made important notes. After that, the researcher also analyzed data related to the content of each source that would be used.

\section{RESEARCH RESULTS}

The results of the literature study and use of literature from 10 scientific articles and journals that have been published on Google Cendikia and preprints.org in the 2019 to 2021 publication period in Indonesian and English can be seen in the table that has been shown below.

\begin{tabular}{|c|c|c|c|}
\hline No. & $\begin{array}{l}\text { Identity of scientific } \\
\text { articles and journals } \\
\text { used }\end{array}$ & $\begin{array}{l}\text { The focus or topic used in } \\
\text { the journals and scientific } \\
\text { articles used }\end{array}$ & $\begin{array}{l}\text { The results of the literature study } \\
\text { obtained }\end{array}$ \\
\hline 1. & $\begin{array}{l}\text { Yudi Latif (2019), } \\
\text { "Identitas } \\
\text { Keindonesiaan dan } \\
\text { Aktualisasi } \\
\text { Pancasila bagi } \\
\text { Generasi Milenial di } \\
\text { Era Digital" }\end{array}$ & $\begin{array}{l}\text { Young people and the } \\
\text { movement became the } \\
\text { shapers of the Indonesian } \\
\text { nationality. These points } \\
\text { of growth, However, the } \\
\text { many conveniences } \\
\text { offered by the } \\
\text { digitalization era make the } \\
\text { spirit of forming } \\
\text { nationalism and } \\
\text { implementing the values } \\
\text { of Pancasila among young } \\
\text { people fade. }\end{array}$ & $\begin{array}{l}\text { In today's digital era, the younger } \\
\text { generation may lose their "youth" } \\
\text { in the sense that the spirit of } \\
\text { discovery, exploration, } \\
\text { willingness to be involved in } \\
\text { national issues is fading. This is } \\
\text { because they do not actualize the } \\
\text { practical values of Pancasila in } \\
\text { facing the challenges of the digital } \\
\text { era. Thus, their youthful spirit has } \\
\text { been eroded by the current rapid } \\
\text { development of digitalization. }\end{array}$ \\
\hline 2. & $\begin{array}{l}\text { Uswatun Hasanah } \\
\text { (2021), } \\
\text { "IMPLEMENTASI } \\
\text { NILAI-NILAI }\end{array}$ & $\begin{array}{l}\text { In the era of the industrial } \\
\text { revolution } 4.0 \quad \text { and } \\
\text { globalization, } \\
\text { characteristic of the }\end{array}$ & $\begin{array}{l}\text { The currents of globalization and } \\
\text { the influence of westernization } \\
\text { that are so large and impact all } \\
\text { aspects of life, including young }\end{array}$ \\
\hline
\end{tabular}




\begin{tabular}{|c|c|c|c|}
\hline & $\begin{array}{l}\text { PANCASILA DI } \\
\text { KALANGAN } \\
\text { GENERASI } \\
\text { MILLENIAL } \\
\text { UNTUK } \\
\text { MEMBENDUNG } \\
\text { DIRI DARI } \\
\text { DAMPAK } \\
\text { NEGATIF } \\
\text { REVOLUSI } \\
\text { INDUTRI 4.0". }\end{array}$ & $\begin{array}{l}\text { nation, } \\
\text { cooperation, has begun to } \\
\text { fade over time, making } \\
\text { individualistic people } \\
\text { have a sense of } \\
\text { Nationalism and } \\
\text { Patriotism less because the } \\
\text { younger generation tends } \\
\text { to imitate the lifestyle of } \\
\text { their idols who come from } \\
\text { abroad. }\end{array}$ & $\begin{array}{l}\text { Indonesians, have made them } \\
\text { slowly leave the characteristics of } \\
\text { their identity and national } \\
\text { character by the values of } \\
\text { Pancasila. So the implementation } \\
\text { of Pancasila values is vital so that } \\
\text { the younger generation is more } \\
\text { familiar with and realizes the } \\
\text { characteristics of the nation and } \\
\text { can shape the character of a } \\
\text { generation that has the spirit of } \\
\text { Pancasila for the progress of the } \\
\text { country because Pancasila can } \\
\text { become a unifying tool for the } \\
\text { Indonesian nation and a source of } \\
\text { value in the life of society, nation, } \\
\text { and state. }\end{array}$ \\
\hline 3. & $\begin{array}{lr}\text { Sovi Dwi } & \text { Febrian } \\
\text { Silva, } & \text { Moses } \\
\text { Glorino Rumambo } \\
\text { Pandin } \\
\text { "Challenges } \quad \text { of } \\
\text { Pancasila Ideology } \\
\text { in the Era of } \\
\text { Industrial } \\
\text { Revolution } \\
\text { Case Study of } \\
\text { Generation Z and } \\
\text { Millennial". }\end{array}$ & $\begin{array}{l}\text { The young generation, or } \\
\text { what is commonly called } \\
\text { the millennials and } \\
\text { generation } Z \text { of Indonesia, } \\
\text { are now facing various } \\
\text { challenges that can } \\
\text { threaten the ideology of } \\
\text { the Indonesian state, } \\
\text { namely Pancasila. }\end{array}$ & $\begin{array}{l}\text { In the current industrial } 4.0 \text { era, } \\
\text { many things threaten the existence } \\
\text { of the Pancasila ideology as the } \\
\text { ideology of the Indonesian state. } \\
\text { The rapid development of } \\
\text { globalization, the industrial } \\
\text { revolution, and technology began } \\
\text { to weaken the position of } \\
\text { Pancasila ideology. This is } \\
\text { reflected in the many deviant } \\
\text { behaviors carried out by young } \\
\text { Indonesians today, which are not } \\
\text { by the values of Pancasila. }\end{array}$ \\
\hline 4. & $\begin{array}{l}\text { Gabriella Raisza } \\
\text { Putri, Moses } \\
\text { Glorino Rumambo } \\
\text { Pandin (2021), "The } \\
\text { Urgency of } \\
\text { Pancasila Values as } \\
\text { a Form of } \\
\text { Millennial } \\
\text { Generation } \\
\text { Character } \\
\text { Education". }\end{array}$ & $\begin{array}{l}\text { Many cases or events } \\
\text { prove that the urgency of } \\
\text { practicing Pancasila } \\
\text { values is increasing. }\end{array}$ & $\begin{array}{l}\text { Currently, the urgency of } \\
\text { implementing Pancasila values } \\
\text { has reached its peak. The amount } \\
\text { of evidence of cases or deviant } \\
\text { behavior of millennials is the most } \\
\text { substantial factor. One example is } \\
\text { young people who insult or } \\
\text { demean other religions on social } \\
\text { media. This is certainly not } \\
\text { following the nation's character } \\
\text { and the values of Pancasila. }\end{array}$ \\
\hline 5. & $\begin{array}{lr}\text { Nabila } & \text { Vidi } \\
\text { Paramestri, } & \text { Moses } \\
\text { Glorino } & \text { Rumambo } \\
\text { Pandin } & (2021), \\
\text { "Lack } & \text { of } \\
\text { Implementation } & \text { of }\end{array}$ & $\begin{array}{l}\text { The lack of public } \\
\text { understanding, especially } \\
\text { of young people, of the } \\
\text { values of Pancasila makes } \\
\text { the level of } \\
\text { implementation of the }\end{array}$ & $\begin{array}{l}\text { This era of globalization has } \\
\text { demanded that anyone be brought } \\
\text { into it. However, the values of } \\
\text { Pancasila must still be upheld and } \\
\text { used as a basis in everyday life. } \\
\text { Unfortunately, this cannot happen }\end{array}$ \\
\hline
\end{tabular}




\begin{tabular}{|c|c|c|c|}
\hline & $\begin{array}{l}\text { Pancasila Values in } \\
\text { the Era of } \\
\text { Globalization". }\end{array}$ & 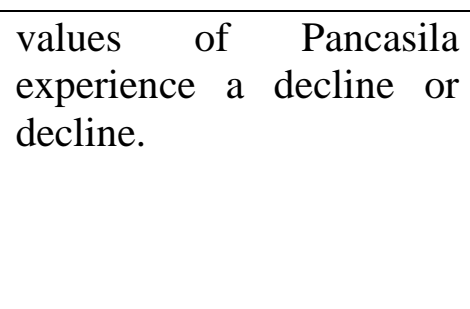 & $\begin{array}{l}\text { because currently, many people } \\
\text { forget the urgency of } \\
\text { implementing Pancasila values so } \\
\text { that deviant behavior arises among } \\
\text { young people such as drugs, free } \\
\text { sex, hoaxes, and the like. }\end{array}$ \\
\hline 6. & 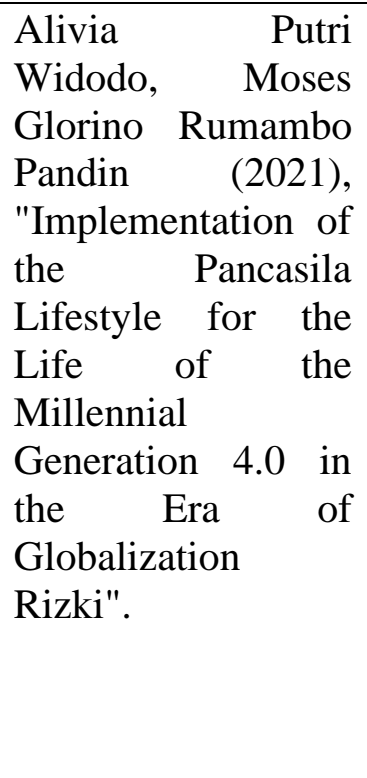 & $\begin{array}{l}\text { The position of Pancasila } \\
\text { as the basis of the state } \\
\text { makes it very important } \\
\text { and mandatory to be } \\
\text { obeyed and used as a basis } \\
\text { both in terms of } \\
\text { government and social } \\
\text { order. }\end{array}$ & $\begin{array}{l}\text { In the era of globalization, many } \\
\text { deviant things are done by the } \\
\text { young generation or Indonesian } \\
\text { millennials. This is evidenced by } \\
\text { some events in Indonesia, such as } \\
\text { brawls, the preservation of a } \\
\text { culture of corruption in schools, } \\
\text { racism with other groups, and hate } \\
\text { speech behavior on social media. } \\
\text { If allowed to continue, small } \\
\text { things like these will be a tragedy } \\
\text { with far-reaching consequences. } \\
\text { As a result, the return and } \\
\text { enhancement of Pancasila value } \\
\text { implementation must be } \\
\text { implemented as soon as possible. }\end{array}$ \\
\hline 7. & $\begin{array}{lr}\begin{array}{l}\text { Dewita } \\
\text { Novianty, }\end{array} \begin{array}{r}\text { Untari } \\
\text { Moses }\end{array} \\
\text { Glorino Rumambo } \\
\text { Pandin } \\
\text { "Analyzing How } \\
\text { Millennial } \\
\text { Generation } \\
\text { Implement } \\
\text { Pancasila Value in } \\
\text { Modern Era". }\end{array}$ & $\begin{array}{l}\text { In today's modern era, } \\
\text { many things make people } \\
\text { start to abandon the values } \\
\text { of Pancasila just like that. } \\
\text { However, the role of } \\
\text { Pancasila is very } \\
\text { influential and essential in } \\
\text { the course of government } \\
\text { in Indonesia. }\end{array}$ & $\begin{array}{l}\text { Currently, many Indonesian } \\
\text { people, especially millennial } \\
\text { youths, forget and leave the values } \\
\text { of Pancasila just like that. } \\
\text { However, after all, Pancasila } \\
\text { values must be implemented } \\
\text { because Pancasila comes from } \\
\text { Indonesia's values and culture. } \\
\text { Therefore, Pancasila should be the } \\
\text { basis for implementing } \\
\text { government in Indonesia, one of } \\
\text { which is guiding making } \\
\text { agreements and national policies. }\end{array}$ \\
\hline 8. & $\begin{array}{l}\text { Feren Alia Hidayat, } \\
\text { Moses Glorino } \\
\text { Rumambo Pandin } \\
(2021) \text {, } \\
\text { "PANCASILA } \\
\text { IDENTITY } \\
\text { AMONG } \\
\text { MILLENNIAL } \\
\text { GENERATION IN } \\
\text { THE } \\
\text { GLOBALIZATION } \\
\text { ERA". }\end{array}$ & $\begin{array}{l}\text { Pancasila is Indonesia's } \\
\text { national identity from the } \\
\text { Indonesian people's rich } \\
\text { culture, customs, and } \\
\text { characteristics. However, } \\
\text { millennials no longer care } \\
\text { about this in the current } \\
\text { era of globalization. }\end{array}$ & $\begin{array}{l}\text { In the current era of globalization, } \\
\text { a national identity, namely } \\
\text { Pancasila, is certainly needed. } \\
\text { Because many challenges that } \\
\text { affect people's behavior can only } \\
\text { be faced with the values of } \\
\text { Pancasila. However, many young } \\
\text { people's behavior is inappropriate } \\
\text { or deviates very far from } \\
\text { Pancasila. Some of these } \\
\text { behaviors are high individualism, } \\
\text { not respecting friends who have }\end{array}$ \\
\hline
\end{tabular}




\begin{tabular}{|c|c|c|c|}
\hline & & & $\begin{array}{l}\text { different opinions, demeaning } \\
\text { friends with different beliefs or } \\
\text { religions, and so on. }\end{array}$ \\
\hline 9. & $\begin{array}{lr}\text { Binov Handitya } \\
\text { (2019), "Menyemai } \\
\text { Nilai Pancasila Pada } \\
\text { Generasi } \\
\text { Cendekia". }\end{array}$ & $\begin{array}{l}\text { The critical role of } \\
\text { Indonesian youth, who are } \\
\text { the golden generation and } \\
\text { the key to national } \\
\text { development in the era of } \\
\text { globalization, is based on } \\
\text { the values of Pancasila. }\end{array}$ & $\begin{array}{l}\text { Youth generation is one of the } \\
\text { most critical assets for the } \\
\text { Indonesian nation in the nation's } \\
\text { development period, meaning that } \\
\text { it is crucial to have the role of } \\
\text { youth in national development. To } \\
\text { become an advanced nation and } \\
\text { compete in the international arena, } \\
\text { the role of youth as the nation's } \\
\text { successor is a mandatory } \\
\text { requirement that must be fulfilled. } \\
\text { As the next generation of the } \\
\text { nation, especially in this } \\
\text { increasingly global and modern } \\
\text { era, they need to get a strong moral } \\
\text { foundation such as understanding } \\
\text { the values of Pancasila, which has } \\
\text { become the basic philosophy of } \\
\text { the nation. }\end{array}$ \\
\hline 10. & $\begin{array}{l}\text { Sahma Nada Afifah } \\
\text { Ekaprasetya, Dinie } \\
\text { Anggraeni Dewi, } \\
\text { Yayang Furi } \\
\text { Furnamasari (2021), } \\
\text { "Menumbuhkan } \\
\text { Jiwa Nasionalisme } \\
\text { Generasi Millenial } \\
\text { di Era Globalisasi } \\
\text { melalui Pancasila". }\end{array}$ & $\begin{array}{l}\text { The rapid flow of } \\
\text { globalization } \\
\text { influencing the lifestyle } \\
\text { and behavior of the } \\
\text { Indonesian people, } \\
\text { especially young people, } \\
\text { has weakened the spirit } \\
\text { and spirit of nationalism } \\
\text { within them. }\end{array}$ & $\begin{array}{l}\text { Pancasila is significant in } \\
\text { everyday life because Pancasila is } \\
\text { an ideology of the Indonesian } \\
\text { nation. Pancasila is also a way of } \\
\text { life for the Indonesian nation. But } \\
\text { along with the times and advances } \\
\text { in technology, it is also due to } \\
\text { current globalization, which has } \\
\text { begun to spread widely among the } \\
\text { people, has caused generations } \\
\text { Millennials are starting to lose the } \\
\text { spirit of nationalism and may } \\
\text { forget the Pancasila ideology, this } \\
\text { can lead to the loss of the identity } \\
\text { of the Indonesian nation, therefore } \\
\text { in it takes an effort to grow the } \\
\text { soul and sense of nationalism of } \\
\text { the youth namely by } 1) \\
\text { Introducing the variety of } \\
\text { Indonesian culture. 2) Using work } \\
\text { products domestic. 3) Educate } \\
\text { children to appreciate differences. } \\
\text { 4) Selective towards the foreign } \\
\text { culture that entered Indonesia. 5) } \\
\text { Introducing Indonesian history. }\end{array}$ \\
\hline
\end{tabular}


The digital era has given many positive impacts and conveniences in every human activity. However, the rapid development of digitalization and technology also brings many new challenges that can affect many aspects of people's lives, especially young people in Indonesia. The service features and conveniences offered should be a stepping stone and things that can make it easier for young people to innovate for the betterment of Indonesia. In fact, the existing facilities have actually made Indonesian young people gradually leave their character and national identity, namely Pancasila.

Pancasila is the ideology, the basis of the state, and the way of life of the Indonesian state. The instrumental, praxis, and axiological values contained therein will undoubtedly be very beneficial and make it easier for young people to reach their goals. However, due to the community's lack of interest, understanding, knowledge, and desire to implement these values, many cases of behavioral deviations occur in the community environment. Some of the factors that make young people lose interest and desire to implement the values of Pancasila are because they think that what is contained in Pancasila is rigid, heavy, too philosophical, and has many perceptions. In addition, the values of Pancasila should indeed be made into a more concrete and easy-to-understand form so that they are adaptive and can be applied in an increasingly advanced era. For example, in the family sphere as the first place for character education, parents can show and model behaviors that reflect the values of Pancasila, such as respecting differences of opinion between family members and being fair to their children. That way, the excellent character will grow in children, which is appropriate and based on the values of Pancasila.

In addition, the national character that has grown in the child must, of course, continue to be fostered and given further understanding. Therefore, Pancasila and Citizenship character education is needed in educational institutions. As has been done by the Minister of Education and Culture, Pancasila character education and citizenship for universities have been mandatory. However, the effectiveness of education and character building is still lacking. This can be seen from the many behaviors of young people, which are inappropriate and far from the values of Pancasila. These deviant behaviors include cheating on exams or cheating, corruption of student organization funds, plagiarism of other people's work, spreading hoax news, and so on.

Steps that can be taken to maximize the Pancasila national character education are by providing understanding and examples of the points of Pancasila to young people as early as possible. As in kindergarten education, children can be introduced to the 5 precepts in Pancasila. In addition, the practical value of Pancasila, which is a further elaboration of the instrumental value of Pancasila, can also be introduced to students through exciting media. For example, through animated videos that show people's behavior according to Pancasila values, such as neighbors of different religions being able to live in harmony and helping each other, mutual tolerance between friends, and friends who respect the opinions of others are different. Visual media such as videos will make it easier for young children to record and take meaning and lessons from the videos shown.

The introduction of the values of Pancasila as early as possible can be one of the preventive and solution steps to grow and develop the national character in Indonesian youth. Because young people are the key to a country's success, the values of Pancasila must exist and be implemented by all young people. If young Indonesians understand and implement the values of Pancasila well, then various challenges in the digital era that can threaten the existence of Pancasila today can be faced. In addition, current technological advances and digitalization can change from a threat to an opportunity and a tool that makes it easier for 
young people to innovate and achieve their progress goals. The Indonesian Pancasila national character that is owned will also continue to live and develop in young people so that nothing can replace the position and existence of Pancasila as the basis of the state, outlook on life, and ideology of Indonesia.

\section{CONCLUSION}

With the advancement of technology and digitalization in Indonesia, which is becoming increasingly advanced and contemporary, the national character of Indonesian society, particularly the younger generation, is vanishing. As a result, Pancasila character education should be included in learning at educational institutions as early as feasible because the nature of early infancy makes it simpler for them to recall items and fundamental knowledge that they were taught when they were little. These items or basic information will subsequently be manifested in their daily lives as conduct. Pancasila character education may be extended to students' understanding of Pancasila for them to be responsible, respect applicable rules, raise the spirit of nationalism, and finish the development of democratic views.

According to data acquired from a study performed by one of the top organizations, namely Microsoft, there are still many discovered on Indonesian social media, such as hoaxes, hatred, and prejudice, which are challenges to Indonesia's national character and unity. Pancasila is a noble principle that must be implemented in the behavior of people's everyday lives to sustain the integrity and character of the nation. Pancasila serves as an ethical behavior guide. Efforts can be made in the community to raise understanding and implementation of Pancasila through educational institutions and by building an obedient and based on Pancasila ideals, such as in the home sphere.

Pancasila represents the nation's identity and character. As a result, to tackle all of the problems of the contemporary digital era, Indonesians, particularly young people, must grasp and put into practice the practical ideals included within to maximize the advantages and functions of the Pancasila philosophy as the nation's ideology. Force cannot be used to instill Pancasila principles in the next generation. The government can better comprehend the spiritual climate of today's youngsters. Furthermore, various visual media and social media can be a valuable option for attracting young people's interest in implementing Pancasila ideals. Other activities, such as scouting with Pancasila ideals, are also possible. The activity is carried out to make the younger generation feel comfortable knowing and adopting Pancasila ideals in their life. As a result, they may ultimately contribute to realizing all Indonesian people's objectives by positively using technical advancements and the present digital environment. 


\section{BIBLIOGRAPHY}

1. Binov handitya. Menyemai Nilai Pancasila Pada Generasi Muda Cendekia. ADIL INDONESIA JURNAL. 2019;2(1):13-22.

10. Yudi Latif. Identitas Keindonesiaan dan Aktualisasi Pancasila bagi Generasi Milenial di Era Digital. Jurnal Kajian Lemhannas RI. 2019;33:5-18.

2. Hidayat, F.A.; Pandin, M.G.R. Pancasila Identity Among Millennial Generation in the Globalization Era. Preprints 2021, 2021060321 (doi: 10.20944/preprints202106.0321.v1).

3. Novianty, D.U.; Pandin, M.G.R. Analyzing How Millennial Generation Implement Pancasila Value in Modern Era. Preprints 2021, 2021060331 (doi: 10.20944/preprints202106.0331.v1).

4. Putri Widodo, R.A.; Pandin, M.G.R. Implementation of the Pancasila Lifestyle for the Life of the Millennial Generation 4.0 in the Era of Globalization. Preprints 2021, 2021060287 (doi: 10.20944/preprints202106.0287.v1).

5. Putri, G.R.; Pandin, M.G.R. The Urgency of Pancasila Values as a Form of Millennial Generation Character Education. Preprints 2021, 2021060301 (doi: 10.20944/preprints202106.0301.v1).

6. Sahma Nada A. E., Dinie A. D., Yayang Furi F. Menumbuhkan Jiwa Nasionalisme Generasi Millenial di Era Globalisasi melalui Pancasila. Jurnal Pendidikan Tambusai. 2021;5(3):78537858.

7. Silva, S.D.F.; Glorino, M. Challenges of Pancasila Ideology in the Era of Industrial Revolution 4.0: Case Study of Generation Z and Millennials. Preprints 2021, 2021060260 (doi: 10.20944/preprints202106.0260.v1).

8. Uswatun Hasanah. Implementasi Nilai-nilai Pancasila di Kalangan Generasi Millenial untuk Membendung Diri dari Dampak Negatif Revolusi Industri 4.0. PEDAGOGY. 2021;8(1):5259.

9. Vidi Paramestri, N.; Rumambo Pandin, M.G. Lack of Implementation of Pancasila Values in the Era of Globalization. Preprints 2021, 2021060381 (doi: 10.20944/preprints202106.0381.v1). 